\title{
A VERDADE FACTUAL RELATIVA NAS DECISÕES JUDICIAIS: UM \\ DIÁLOGO INTERDISCIPLINAR COM O FILME DOZE HOMENS E UMA SENTENÇA
}

THE RELATIVE FACTUAL TRUTH IN THE JUDICIAL DECISIONS: AN INTERDISCIPLINARY

DIALOGUE WITH THE MOVIE 12 ANGRY MEN

Mara Regina de Oliveira'

\begin{abstract}
Resumo:
Este artigo parte da hipótese de que a decisão jurídica não se reduz a um silogismo jurídico, o qual se restringiria à exposição declaratória e mecanicista da norma geral. A verdade factual não pode ser captada pelo Direito, no momento de sua aplicação prática. Ela é substituída pelo pela ideia de "fato verificado juridicamente" o raciocínio decisório é constitutivo porque envolve um discurso hermenêutico complexo. Em uma perspectiva interdisciplinar, analisamos a linguagem imaginética do filme Doze Homens e uma sentença (Sidney Lumet, 1957).
\end{abstract}

Palavras-chaves: Decisão. Silogismo. Verdade. Linguagem. Justiça. Cinema. Direito. Interpretação.

\begin{abstract}
:
This article considers the hypothesis that the legal decision is not merely a legal syllogism, which would be restricted to exposure of the declaratory and mechanist general rule. The factual truth cannot be captured by the law, at time of its practical application. It is replaced by the idea of "legally verified fact". the reasoning is a constitutive decision because it involves a complex hermeneutical discourse. From an interdisciplinary perspective, we analyze the movie 12 Angry Men (Sidney Lumet, 1957)
\end{abstract}

Keywords: Decision. Syllogism. Truth. Language. Justice. Cinema. Law. Interpretation.

É possível que seja um problema interessante de psicologia social determinar o porquê se deseja ocultar o que realmente ocorre na administração da justiça. Aqui devemos nos contentar em asseverar que parece um fenômeno universal simular que a administração da justiça constitui uma simples dedução lógica de regras jurídicas, sem nenhuma valoração por parte do juiz. ${ }^{1}$

Mestre e Doutora em Filosofia do Direito, pela Faculdade de Direito da Pontifícia Universidade Católica de São Paulo, onde leciona a disciplina Filosofia do Direito, na condição de Professora Assistente Doutora. É Professora Doutora da Faculdade de Direito da Universidade de São Paulo, onde leciona, na pós-graduação, a disciplina Cinema e Filosofia do Direito: o problema da verdade e da justiça no exercício jurídico do poder.

1 ROSS, Alf. Direito e Justiça. Bauru: Edipro, 2003. p. 184-185. 
Introdução

A peça teatral Faith Healer, escrita pelo irlandês Brian Friel, traduzida em recente montagem paulistana como $O$ Fantástico Reparador de Feridas, traz um instigante questionamento em torno da possibilidade da objetividade da narrativa de um evento factual. Ela é composta por quatro monólogos, onde três personagens, que viajaram juntos pelo interior da Escócia, contam para o espectador, sua versão sobre certos eventos traumáticos, em termos emocionais, que viveram juntos, no passado. $\mathrm{O}$ aspecto instigante da peça é que, a partir do momento que começamos a comparar os discursos, nos colocando quase na posição de analistas psicológicos dos personagens, percebemos que as narrativas são contraditórias e discordantes entre si. ${ }^{2}$

Frank é o "faith healer", um personagem atormentado, que abusa da bebida, por não ter controle do seu dom da cura. Ele demonstra cinismo e ao mesmo tempo angústia diante desta incerteza. Grace, sua esposa, é filha de um conhecido advogado, mas vive uma conturbada e ambígua relação com a Frank, que oscila entre o amor e o ódio diante da sua dependência emocional em relação ao seu companheiro, que mostra traços de crueldade em relação a ela. Teddy é o empresário decadente de Frank, que também é alcoólatra e busca defender, a princípio, o não envolvimento emocional na profissão, mas, paradoxalmente, acaba por demostrar grande admiração pessoal por Frank e talvez uma paixão não assumida por Grace. Observamos, nos três personagens, uma grande fragilidade emocional e uma marcante distância entre a fala verbalmente posta para 0 público (como eles se veem) e aquilo que a figura deles comunica no palco como um todo (como eles podem ser vistos por terceiros). Há uma grande diferença entre a imagem que cada um faz de si próprio e como são vistos um pelo outro, do ponto de vista externo. A peça termina sem que possamos saber o que de fato aconteceu, a incerteza sobre a narrativa dos fatos permanece em aberto. O que observamos com exatidão é a incongruência discursiva entre os três personagens e a certeza da dúvida sobre as variadas e antagônicas percepções do real.

Conforme expõe Edgar Morin, pelo processo psicológico da projeção, como processo universal e multiforme, as nossas necessidades, aspirações, desejos, obsessões projetam-se, não só no vácuo dos sonhos e imaginação, mas sobre as coisas e os seres. Isto explica os relatos contraditórios de um mesmo acontecimento, mais inconscientes do que intencionais. A crítica histórica ou psicológica do testemunho revela que as nossas percepções elementares (como a percepção da estatura de alguém) são confundidas

2 Assistimos esta peça, em Dublin, no Gate Theatre, sob a direção de Jonathan Kent, tendo os atores Ralph Fiennes (Frank Hardy), Ingrid Craigie (Grace) e Ian MacDiarmid (Teddy), nos papéis principais. Em São Paulo, assistimos em 2010, a montagem feita pela Cia Ludens, no Viga Espaço Cênico, tendo os atores Walter Breda ( Frank Hard), Mariana Muniz (Grace) e Rubens Caribé ( Teddy). 
e trabalhadas pelas nossas projeções. Sempre atribuímos a alguém que julgamos as tendências que nos são próprias. Tudo é puro para os puros e impuro para os impuros. ${ }^{3}$

A obra teatral discute como elementos psicológicos subjetivos interferem no testemunho pessoal da percepção da realidade de Frank, Grace e Teddy, enquanto elemento linguístico relevante. Eles questionam o nosso senso comum linguístico ingênuo, voltado para a ideia da língua como representação objetiva do mundo real, capaz de captar a chamada verdade factual. Assistindo a montagem irlandesa, lembramo-nos de como seria possível relacionar esta discussão com a narrativa dos fatos, no âmbito judicial. Mas é também possível pensar nesta mesma incerteza narrativa projetada no processo decisório jurídico. Do ponto de vista dogmático, admite-se a possibilidade da verdade factual e abstrai-se o complexo problema da imprecisão linguística e da subjetividade do intérprete. Parte-se do pressuposto de que seria possível descrever os fatos com objetividade e subsumi-lo à normal geral, com precisão lógica absoluta.

A proposta deste artigo é ir além desta simplificação dogmática, em parte justificada pela necessidade prática de promover a decidibilidade conflitos, com o mínimo de perturbação social possível. Pretendemos fazer uma análise zetética e interdisciplinar do problema da verdade factual no fenômeno decisório linguístico, colocando em discussão o problema da incerteza da narrativa. Em termos metodológicos, relacionaremos algumas teorias críticas do direito com a linguagem imaginética do cinema, porque consideramos, que ela, assim como o teatro, teria o dom de captar as complexidades humanas, que envolvem o fenômeno decisório, na sua base real, tendo em vista o seu aspecto comunicativo profundo, sem fazer concessões simplificadoras. Escolhemos para a análise o brilhante filme Doze homens e uma sentença (Sidney Lumet, 1957), que, na esteira do filósofo Julio Cabrera, nos faz pensar em termos logopáticos sobre o problema da verdade e da justiça no processo judicial. A seguir, antes de entrar propriamente na análise do filme, vamos expor, em linhas gerais, reflexões sobre esta possibilidade de relacionamento do cinema com o pensar filosófico-crítico, que, para nós, não apenas permite uma exemplificação das teorias, mas uma expansão do próprio pensar filosófico em si mesmo.

1. Cinema e pensamento filosófico: um diálogo possível

Em um instigante livro intitulado "O Cinema Pensa: uma introdução à filosofia através dos filmes" o filósofo argentino, radicado no Brasil, Julio Cabrera, defende a importante tese de que a filosofia, ao invés de ser considerada como algo concebido, historicamente, antes do cinema, poderia ser entendida como um saber mutável

MORIN, Edgard. A alma do cinema. In: XAVIER, Ismail (Org.). A Experiência do cinema: antologia. Rio de Janeiro: Edições Graal: Embrafilmes, 2008. p. 146. 
que se modifica através do diálogo com a chamada sétima arte, como elemento cultural relevante. Neste sentido, o pensar através da interpretação de imagens em movimento (ou em ilusão de movimento) assume um contorno não apenas voltado à racionalidade lógica, mas, também, a uma cognição da realidade que inclui um elemento afetivo (pático), primordial. ${ }^{4}$ Segundo o autor, alguns filósofos como Kierkegaard, Schopenhauer, Heidegger e Nietzsche poderiam ser considerados filósofos páticos (a palavra pático vem do grego phátos, que diz respeito àquilo que manifesta emoções) que, de certa forma, anteciparam um tipo de reflexão humana no campo da linguagem escrita, próxima a que será viabilizada pelo cinema posteriormente, através de imagens. ${ }^{5}$

Esclarece o autor que, embora os chamados filósofos lógicos ou apáticos, como Aristóteles, São Tomás, Descartes, Locke, Hume, Kant e Wittgenstein, tenham, eventualmente, formulado o problema do impacto da emoção na razão filosófica, como tema, os filósofos páticos, citados no parágrafo anterior, foram muito além, incluindo a afetividade como elemento constitutivo da racionalidade, do ponto de vista interno e não apenas externo. Citando Heidegger, ele afirma:

Dentre todos os filósofos, foi ele que expressou de maneira mais clara este compromisso da filosofia com um pathos de caráter fundamental, quando fala, por exemplo, da angústia e do tédio como sentimentos que nos colocam em contato com o ser do mundo, como sentimentos com valor cognitivo (no sentido amplo de um "acesso" ao mundo, não de um sentido epistemológico). Ao referir à poesia como "pensante" e não apenas como um fenômeno estético ou um desabafo emocional- ela a considera essencialmente apta a expressa a verdade do ser. ${ }^{6}$

Para a compreensão profunda de um problema filosófico, não basta entendêlo, racionalmente, como conceito teórico/semântico. Temos de vivê-lo, senti-lo, ser afetado por ele, como uma experiência emocional, não empírica, que aguce a nossa sensibilidade cognitiva, próxima de uma dimensão que poderíamos chamar de pragmático-impactante, a qual deve produzir algum tipo de transformação. Embora a forma literária tenha preponderado na história do pensamento filosófico, nada impediria que se viabilizasse uma problematização filosófica, através da análise de imagens do cinema, da fotografia, da ópera ou da dança. ${ }^{7}$ Mais adiante, ele levanta a polêmica hipótese de que o cinema seria uma linguagem mais apropriada do que a própria escrita nesta forma de pensar dos

\footnotetext{
4 CABRERA, Julio. O cinema pensa: uma introdução à filosofia através dos filmes. Rio de Janeiro: Rocco, 2006. p. $15-16$ Id. Ibid.

Id. Ibid., p. 19

Id. Ibid., p. 17
} 
filósofos, que ele chama de logopáticos. Algumas questões humanas não podem apenas ser ditas e articuladas logicamente. Elas devem ser apresentadas, sensivelmente, por meio de uma compreensão logopática, racional e afetiva, que, longe de ser uma mera impressão psicológica, tem pretensão de verdade universal. Como forma de pensamento, ele é tão aberto como a filosofia dita literária, não existe uma definição que o alcance em termos absolutos. ${ }^{8}$

Cabe aqui mencionar o pensamento de Jean Epstein sobre a questão. Como Cabrera, ele destaca a grande proximidade simbólica da imagem com a realidade sensível, que ela representa, em comparação com a palavra, que apresentaria uma espécie de símbolo indireto, elaborado pela razão, relacionado ao poder de abstrair, classificar e deduzir. A percepção da imagem em movimento constitui uma significação semipronta, que alcança, de forma contundente e indutiva, a emotividade do espectador, sem a mediação do raciocínio abstrato. Já a palavra, para produzir uma emoção, depende de uma prévia decodificação racional de seu significado, para que represente uma realidade e esteja apta a mexer com sentimentos. Nas suas considerações:

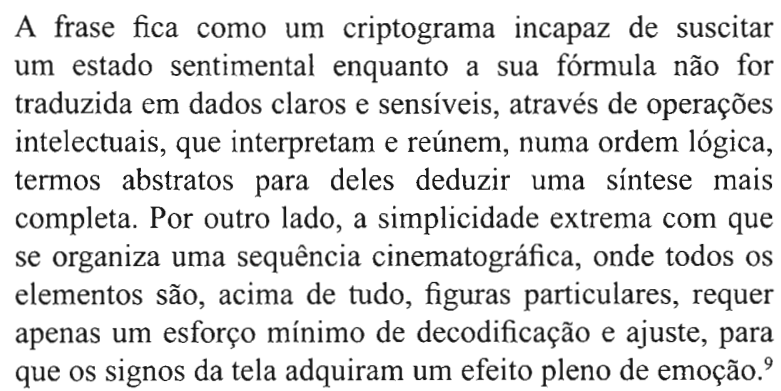

Para que a linguagem cinematográfica seja vista, do ponto de vista filosófico, é necessário que percebamos que ela se constrói a partir dos chamados "conceitosimagem", que não se confundem com os tradicionais "conceitos-ideia" trabalhados na filosofia escrita. No pensamento de Cabrera, eles não têm um caráter essencialista e definitivo, mas heurístico e crítico. Eles caracterizam uma experiência que se tem para que possamos entender e trabalhar este conceito, na forma de um "fazer coisa com imagens" Nas palavras do autor:

A racionalidade logopática do cinema muda a estrutura habitualmente aceita do saber, enquanto definido apenas lógica ou intelectualmente. Saber algo, do ponto de vista logopático, não consiste somente em ter informações, mas

8 CABRERA, Julio. O cinema pensa: uma introdução à filosofia através dos filmes. Rio de Janeiro: Rocco, 2006. p. 18

9 EPSTEIN, Jean. O cinema do diabo-excertos. In: XAVIER, Ismail (Org.). A experiência do cinema: antologia. Rio de Janeiro: Edições Graal: Embrafilmes, 2008. p. 294. 
também em estar aberto a certo tipo de experiência e em aceitar, deixar-se afetar por uma coisa de dentro dela mesma, em uma experiência vivida. ${ }^{10}$

Não se trata, apenas, de assistir ao filme como uma experiência estética ou social desarticulada do raciocínio ou ler um comentário sobre a película, mas de desenvolver uma interação lógico-afetiva, que evidencie a presença de conceitos ou ideias nas imagens em movimento. Já entendemos como a linguagem do cinema é poderosa porque produz a famosa "impressão da realidade" acompanhada pela identificação com o olhar dos personagens, numa situação dinâmica de espacialidade e temporalidade construídas. Os conceitos-imagem do cinema produzem um impacto emocional sobre questões que dizem respeito ao humano, com valor cognitivo, persuasivo, unindo lógica e pática, concomitantemente. Este impacto emocional não está ligado a um possível efeito dramático de um filme, do tipo melodrama, muitos filmes considerados "cerebrais" comovem o espectador pela sua "frieza" Por mais racional que seja um filme, ele nunca será abstrato como um tratado literário filosófico.

Neste sentido, cabe lembrar da didática distinção feita por Hugo Munsterberg a respeito das emoções provocadas pelo cinema. Em primeiro lugar, teríamos as emoções que os personagens comunicam de dentro do filme, provocando simpatia pelo sofrimento ou mesmo compartilhando as alegrias pelo amor realizado A percepção visual das várias manifestações dessas emoções se funde em nossa mente com a consciência da emoção manifestada. É como se estivéssemos vendo e observando diretamente a própria emoção. Reagimos, organicamente, de forma adequada, o horror nos dá arrepios, a felicidade nos acalma. Há uma experiência viva do reflexo emocional dentro da nossa mente. Nos filmes melodramáticos, este tipo emoção está muito presente. Mas, haveria, por assim dizer, um segundo tipo de emoção secundária em que a plateia reage às cenas do filme do ponto de vista da sua vida afetiva independente, onde pode haver, portanto, uma indignação moral e não uma identificação emotiva com o personagem. A nosso ver, estas duas formam de emotividade se combinam na experiência do cinema, mas a emoção secundária estaria mais presente nos chamados filmes "cerebrais" e seria muito útil em atividades acadêmicas interdisciplinares. ${ }^{11}$

A pretensão de universalidade da reflexão filosófico-cinematográfica está ligada à ideia de possibilidade e não de necessidade. Temos a constatação de que, embora não aconteça necessariamente com todos, poderia acontecer com qualquer um. ${ }^{12}$

10 CABRERA, Julio. O cinema pensa: uma introdução à filosofia através dos filmes. Rio de Janeiro: Rocco, 2006. p. 21.

" MUNSTERBERG Hugo. As emoções. In: XAVIER, Ismail (Org.). A experiência do cinema: antologia. Rio de Janeiro: Edições Graal: Embrafilmes, 2008. p. 52-53.

12 CABRERA, Julio. O cinema pensa: uma introdução à filosofia através dos filmes. Rio de Janeiro: Rocco, 
Um filme por inteiro pode ser a expressão de um conceito-imagem de uma ou múltiplas noções. Temos, neste caso, um macro conceito-imagem que é formado a partir de outros conceitos-imagem menores, que requerem certo tempo cinematográfico para o seu desenvolvimento temporal, uma única cena não pode constituir um conceitoimagem. ${ }^{13}$ Eles podem ser percebidos, literalmente, nas imagens exibidas, ou serem captados de forma abstrata e metafórica, tornando plena a sua conceituação filosófica. ${ }^{14}$

A produção do impacto emocional é fundamental para a eficácia cognitiva do conceito-imagem. A técnica cinematográfica se vale da pluriperspectiva, da manipulação do tempo e espaço e do corte cinematográfico para viabilizar este efeito estético. A pluriperspectiva se constitui graças a sua capacidade de dar "saltos" da primeira (o que vê ou sente o personagem), que é subjetiva, para a terceira, que é objetiva (o que vê a câmera). Neste sentido, a montagem, dentro dos planos, o ângulo aberto ou fechado da câmera e seu movimento podem tornar intensa a experiência do cinema. Isto se associa à enorme capacidade de manipular tempo e espaço, avançar e retroceder, inverter ou mesclar a ordem cronológica do passado e do futuro, mostrar espaços simultâneos, e articular o literal e o metafórico, como só os sonhos podem. Por fim, temos a maneira aberta e plural de conectar os planos, as cenas e as sequências. ${ }^{15}$

A técnica cinematográfica possibilita a instauração da experiência logopática, a qual permite a manifestação dos conceitos-imagem, que só podem ser gerados por ela e não por meios literários ou fotográficos. Outra característica importante seria a de que eles sempre apresentam desfechos abertos a novas problematizações filosóficas, mesmo que a intenção do diretor seja a de fechá-las. A linguagem da imagem tem uma natureza subversiva em termos de estrutura. Neste sentido, as soluções lógicas da filosofia escrita geralmente têm uma intenção de apresentar conclusões mais conciliadoras, conservadoras e construtivas, simbolicamente, bem educadas, como uma tentativa de "resolver o mundo dentro da cabeça" que o cinema não consegue fazer, mesmo que tente. ${ }^{16}$

Cabrera também levanta o problema da verdade universal filosófica na linguagem do cinema que se vale de uma "impressão de realidade" e pela possibilidade de apresentar a mais inverossímil fantasia como aparência de realidade de maneira retórica e até declaradamente mentirosa. Não esqueçamos de que parte da tradição filosófica reverencia a verdade como algo que pode estar livre de ilusões e equívocos. Como conciliar esta simulação do real com a pretensão de verdade ? $^{17}$

\footnotetext{
2006. p. 23.

13 Id. Ibid., p. 24.

Id. Ibid., p. 26.

15 CABRERA, Julio. O cinema pensa: uma introdução à filosofia através dos filmes. Rio de Janeiro: Rocco, 2006. p. 31-32.

16 Id. Ibid., p. 34.

17 Id. Ibid., p. 37.
} 
O autor entende que tanto as ciências como as filosofias escritas estão cheias de simulações, de exemplos fantasiosos para o desenvolvimento de suas questões. Em todos os filmes, o problema do universal/particular está presente na própria experiência do cinema, como uma espécie de problematicidade intrínseca da imagem, através do impacto emocional que provoca. Este impinge uma noção de verdade, quase visceral, que passa pelas entranhas até chegar ao cérebro, mais do que poderia fazer um tradicional texto filosófico escrito. Nestes termos, a leitura filosófica de um filme, ao compor elementos lógicos e afetivos, está direcionada a particulares que suscitam e que manifestam as emoções, mas "a própria reflexão logopática, que ela gera, tem um alcance universal, que nos permite pensar o mundo de forma geral, muito além do que é simplesmente mostrado no filme" ${ }^{18}$ A leitura filosófica de um filme, ao compor elementos lógicos e afetivos, está direcionada a particulares que suscitam e que manifestam as emoções, mas a própria reflexão logopática que ela gera tem um alcance universal, que nos permite pensar o mundo de forma geral, muito além do que é simplesmente mostrado no filme. Nas palavras do autor, "enquanto a filosofia escrita pretende desenvolver um universal sem exceções, o cinema apresenta uma exceção com características universais" 19

Por último, o autor faz um importante alerta, relativo ao problema da imagem poder, eventualmente, impingir a sua manipulação retórica emocional de forma abusiva e distorcida. Ele cita o exemplo dos filmes de propaganda nazista, que ajudaram a disseminar a banalidade do mal entre o povo alemão. Sempre é necessário que haja uma informação exterior racional, que não venha da própria imagem. Desse modo, o que as asserções imaginéticas nos mostram não deve ser assumido como verdadeiro, sem maiores ponderações críticas, de forma similar ao que ocorre nas proposições filosóficas escritas. $\mathrm{Na}$ percepção do filme, o aspecto emocional interage, permanentemente, com o aspecto lógico. Neste sentido, diz o autor:

Podemos negar a verdade que a imagem cinematográfica nos tenta impor. A mediação emocional tem a ver com a apresentação da ideias filosófica e não com a sua aceitação impositiva. Devemos nos emocionar para entender e não necessariamente para aceitar. Não é que a emoção da imagem nos mostre imediatamente uma verdade, ela nos apresenta, impositivamente, um sentido, uma possibilidade. Mas o sentido de uma imagem, como o sentido de uma proposição, é anterior à sua verdade ou falsidade. ${ }^{20}$

\footnotetext{
CABRERA, Julio. O cinema pensa: uma introdução à filosofia através dos filmes. Rio de Janeiro: Rocco, 2006. p. 39.

19 Id. Ibid., p. 42

20 Id. Ibid., p. 40-41.
} 
Partindo desta reflexão de Cabrera, voltada para a filosofia geral, entendemos que, no campo da teoria do direito, existem instigantes linhas filosóficas literárias práticas, que permitem uma aproximação muito rica com a linguagem imaginética na apreensão de temas, que envolvem uma delicadeza sutil da compreensão do humano, em uma dimensão mais profunda. Toda a discussão teórico-filosófica sobre a relação entre direito, verdade e justiça, no plano real dos fatos e das condutas efetivas, envolve esta aproximação experiencial emotiva que vai muito além da racional compreensão semântico-lógica de enunciados escritos nos textos legais dogmáticos. Trata-se de um ramo do direito onde o humano envolve-se, diretamente, nas questões teóricas primordiais, principalmente quando indagamos a respeito da sua imperatividade concreta.

\section{As imprecisões linguísticas presentes no momento da aplicação do Direito}

De acordo com Tercio Sampaio Ferraz Junior, as teorias dogmáticas estudam o Direito a partir de sua capacidade de institucionalizar e decidir os conflitos sociais, do ponto de vista jurídico. Para tanto, abstraem todas as questões zetéticas de realidade, que permeiam o fenômeno normativo, que poderiam postergar esta tomada de decisão e comprometer o ideal de segurança jurídica. Um dos cânones balizares das teorias dogmáticas da decisão é a ideia de que o raciocínio, no âmbito legislativo, administrativo e judicial, reduz-se, no seu aspecto formal, a um mero raciocínio silogístico dedutivo que teria a seguinte estrutura básica: a norma geral seria a premissa maior, a descrição do caso seria a premissa menor e a conclusão seria o ato decisório em sentido estrito. ${ }^{21}$ Como no exemplo:

Se um indivíduo matar alguém, deve ser punido com pena de reclusão de seis a vinte anos.

João matou seu pai.

Logo, João deve ser punido com pena de reclusão de 15 anos.

De um ponto de vista zetético, todavia, a realidade linguística que compõe o raciocínio decisório é muito mais complexa, pois vai muito além da visão aparentemente mecânica e simplista do raciocínio lógico-formal. A subsunção, que consiste no ato de submeter o caso à regra, depende da construção da premissa maior, que se relaciona tanto com a sua complicada interpretação semântica, como na verificação da sua validade normativa, em relação às demais normas do sistema jurídico. Nesta perspectiva, a premissa maior normativa não é um dado, ela traz elementos prescritivos de dever ser, ela

21 FERRAZ JUNIOR, Tercio Sampaio. Introdução ao estudo do direito: técnica, decisão, dominação. 4. ed. São Paulo: Atlas, 2003. p. 316. 
tipifica a hipótese normativa "matar alguém" ao imputar uma consequência normativa sancionadora "pena de reclusão de 6 a 20 anos" 22

Hans Kelsen, numa perspectiva semelhante, considera que o raciocínio decisório tem uma natureza constitutiva e não apenas declaratória da norma geral. O julgador não teria de descobrir e declarar um direito já de antemão firme a acabado, cuja produção já foi concluída na norma geral. A aplicação (individualização) das normas jurídicas gerais depende da verificação, no caso concreto apresentado, de que existem in concreto os pressupostos in abstracto, determinados pela norma geral (questões de fato). A norma individual, que impõe uma sanção concreta, seria constituída e criada só através da decisão judicial. ${ }^{23}$

No âmbito da construção da premissa maior, temos de enfrentar o problema semântico do caráter convencional e equívoco da linguagem. A relação entre língua e realidade não é natural nem essencial em termos universais, mas arbitrariamente construída pelas interações humanas. Os conceitos não descrevem uma realidade posta a priori, pois é a partir dos conceitos mutáveis, em termos históricos, que descrevemos a própria realidade, em seu aspecto dinâmico. Como os usos linguísticos variam no tempo e espaço temos o problema da vagueza e da ambiguidade de seus termos. Os conceitos vagos são aqueles que a doutrina costuma chamar de conceitos indeterminados, na medida em que sua extensão denotativa é imprecisa. Como exemplo, mencionamos expressões "perigo eminente", "meios necessários" "ruído excessivo" "moderadamente" Já os conceitos ambíguos ocorrem na medida em que sua intenção conotativa é sempre dúbia, como no caso "boa-fé" "mulher honesta" "injusta agressão" Muitas vezes, a norma estabelece, explicitamente, um espaço da discricionariedade do julgador para adaptar a norma a situações fáticas distintas, por exemplo, uma pena mínima de seis e pena uma máxima, de vinte anos. ${ }^{24}$

Al Ross, em linha de raciocínio semelhante, considera que a referência semântica das palavras, do ponto de vista convencional, é constituída por uma zona central sólida em que a sua aplicação é predominante e certa, e um círculo nebuloso exterior de incerteza, no qual a sua aplicação é menos usual e no qual se torna duvidoso saber se a palavra pode ser aplicada ou não. A vagueza afeta todas as palavras, diz respeito ao fato de seu campo de referência ser indefinido. A zona central se transforma, gradualmente, num círculo de incerteza. A ambiguidade, que está presente na maioria das palavras, diz

22 FERRAZ JUNIOR, Tercio Sampaio. Introdução ao estudo do direito: técnica, decisão, dominação. 4. ed. São Paulo: Atlas, 2003. p. 317.

23 KELSEN, Hans. Teoria pura do direito. São Paulo: Martins Fontes, 1987. p. 255.

24 FERRAZ JUNIOR, Tercio Sampaio. Introdução ao estudo do direito: técnica, decisão, dominação. 4. ed. São Paulo: Atlas, 2003. p. 318. 
respeito ao fato das palavras não terem um campo de referência único, mas múltiplo. ${ }^{25}$ Para citar as palavras do autor:

De todos os sistemas de símbolos, a linguagem é o mais plenamente desenvolvido, o mais eficaz e o mais complicado. A linguagem pode manifestar-se como uma série de formas auditivas ou visuais (fala e escrita). O significado atribuído a estas formas é claramente convencional. Nada impediria que a palavra gato fosse empregada para designar o animal doméstico com quatro patas que faz "uau, uau" e cão para designar o que faz "miau". O significado atribuído aos símbolos linguísticos é determinado pelos costumes da comunidade referentes às circunstâncias nas quais se considera adequado emitir certos sons. ${ }^{26}$

Hans Kelsen, no último capítulo da Teoria Pura do Direito, refutando, com veemência, a possibilidade da interpretação normativa correta ou verdadeira, fala a respeito das indeterminações intencionais e não intencionais que são percebidas linguisticamente no ato de aplicação do direito. As intencionais, como o próprio nome indica, são aquelas postas de forma consciente pelo órgão criador da norma a ser aplicada, a fim de que o aplicador determine critérios específicos para cada caso. Ele cita o exemplo da lei penal que prevê para um mesmo delito a aplicação da pena de multa e da pena de prisão, cabendo ao juiz, no caso concreto, decidir por uma ou pela outra. Já as indeterminações não intencionais seriam muito mais complexas porque não emanam da vontade do legislador, mas do aspecto social e não natural da linguagem. Palavras idênticas podem ter significados diferentes, o "sentido verbal não é unívoco, o órgão que tem de aplicar a norma encontra-se perante várias significações possiveis" Nas palavras de Hans Kelsen, a interpretação cognoscitiva leva a percepção da "moldura" que pode ser preenchida com significados semânticos distintos. ${ }^{27}$

Nesta atividade cognoscitiva do órgão aplicador do direito, não há formação de raciocínios "puros" pois há a incidência de normas morais, normas de justiça e juízos sociais de valor que não fazem parte do Direito Positivo propriamente e que para o autor são normas relativas, jamais universais. Ele conclui, neste sentido, que "a interpretação de uma lei não deve conduzir a uma única solução como sendo a única correta, mas possivelmente a várias soluções que têm igual valor" Do ponto de vista estritamente científico, caberia apenas elencar os diversos sentidos possíveis, sem qualquer vinculação com a prática efetiva. Mas esta incerteza linguística não impede a tarefa dogmática do direito, que para ele está no campo da política jurídica e não da ciência pura. O autor ressalta

ROSS, Alf. Direito e justiça. Bauru. São Paulo: Edipro, 2003. p. 142.

Id. Ibid., p. 140.

27 KELSEN, Hans. Teoria pura do direito. São Paulo: Martins Fontes, 1987. p. 364-366. 
que no momento da aplicação, esta interpretação cognoscitiva, ligada ao conhecimento dos múltiplos sentidos semânticos, se combina com um ato volitivo que escolhe um dos sentidos possíveis revelados através da sua percepção cognitiva. Esta interpretação tornase "autêntica" porque cria direito, não porque seja, de fato, como defende a doutrina tradicional, a mais correta ou a mais justa, do ponto de vista valorativo. ${ }^{28}$

Al Ross entende que a inevitável imprecisão das palavras torna possível tanto abarcar os fatos, como não abarcar, tendo em vista o significado da lei. O juiz terá de escolher, sempre influenciado por uma valoração. A interpretação é um ato de natureza construtiva que é motivada tanto pela consciência jurídica formal, como pela consciência jurídica material. A consciência jurídica formal diz respeito ao dogma de obediência ao direito. A consciência jurídica material relaciona-se à tradição cultural (ideais, posturas, valorações) que vive no espírito do juiz. Ele interpreta a lei à luz desta consciência, a fim de que sua decisão seja aceita como correta e como justa ou socialmente desejável. Graças a uma técnica de argumentação, o juiz aparenta que sua argumentação pode ser deduzida da verdadeira interpretação da lei ${ }^{29}$ Recaséns Siches, numa linha semelhante de raciocínio, entende que esta materialidade valorativa, intrínseca, a qualquer julgamento, estaria sempre a serviço de um ideal de justiça humanitário e prudencial. ${ }^{30}$

O exame da premissa menor não é menos problemático, na medida em que diz respeito ao tema da prova jurídica. A palavra probatio advém de probus que gerou, em português, prova e probo. Tercio Sampaio Ferraz Jr levanta o problema do duplo sentido da palavra "prova" que aponta, em seu sentido objetivo, a demonstração de um fato ocorrido e em seu sentido subjetivo, fazer aprovar, inspirando simpatia e confiança, permitindo o entendimento dos fatos em sentido favorável, envolvendo diretamente o problema da justiça. ${ }^{3 !}$

Segundo Hans Kelsen, não só a interpretação da norma geral, mas também a averiguação do fato delituoso teria um caráter constitutivo. O tribunal determina o órgão para verificar se o fato ocorreu concretamente, a fim de que entre no domínio do direito. Não é o fato em si de alguém ter cometido um homicídio que constitui o pressuposto estatuído pela ordem jurídica, mas o fato de um órgão competente juridicamente ter verificado, num processo determinado pela ordem jurídica, que um indivíduo praticou um homicídio. O suspeito pode confessar ou negar o fato, mas apenas importam as opiniões

\footnotetext{
28 KELSEN, Hans. Teoria pura do direito. São Paulo: Martins Fontes, 1987. p. 365.

29 ROSS, Alf. Direito e Justiça. Bauru: Edipro, 2003. p. 168.

30 PRADO, Lídia Reis de Almeida. Alguns aspectos sobre a lógica do razoável na interpretação do direito (Segundo a visão de Recaséns Sic hes). In: DI GIORGI, Beatriz; CAMPILONGO, Celso Fernandes; PIOVESAN, Flávia (Coord.). Direito, cidadania e justiça: ensaios sobre lógica, interpretação, teoria, sociologia e filosofia jurídicas. São Paulo: Editora dos Tribunais, 1995. p. 61-74.

31 FERRAZ JUNIOR, Tercio Sampaio. Introdução ao estudo do direito: técnica, decisão, dominação. 4. ed. São Paulo: Atlas, 2003. p. 319.
} 
dos indivíduos encarregados de aplicar o direito, que podem até contradizer-se. Todavia, só uma opinião pode prevalecer, na medida em que ela é juridicamente relevante, só podendo ser atacada por meio de recurso, até que transite em julgado. $O$ tribunal pode verificar que um determinado indivíduo praticou um homicídio, embora, na realidade, ele não tenha ocorrido, ou o tribunal pode verificar que um indivíduo não praticou um homicídio, embora, na realidade, ele tenha executado tal homicídio. $\mathrm{O}$ fato processualmente verificado vem ocupar o lugar do fato em $\mathrm{si}^{32}$ De acordo com este pensador, teríamos que reformular o silogismo na seguinte forma:

\section{Se um indivíduo matar alguém, deve ser punido com pena de reclusão de 6 a 20 anos. \\ (Pressupostos e consequências abstratas) \\ Pelo processo, verificou-se que João matou seu pai. \\ (Verificação concreta e constitutiva dos fatos, problema da prova) \\ Logo, João deve ser punido com pena de 15 anos de reclusão. (Ordem concreta da sanção)}

Tercio Sampaio Ferraz Jr, ao analisar o pensamento de Hans Kelsen no tocante ao problema da segunda premissa, considera que as relações fáticas, do ponto de vista jurídico, não se ligam ao princípio da causalidade, mas sim ao da imputação. Embora ele considere que a imputação normativa não possa ignorar o nexo causal, em termos absolutos (se o nexo causal é impossível, a imputação perde o sentido) provar um fato, em termos jurídicos, significa uma questão normativa de atribuição de consequências à conduta e não uma relação causal. Assim, não se prova se "A pagou X para B, mas sim se houve um pagamento, em termos jurídicos." ${ }^{33}$

Em síntese, podemos afirmar que, segundo este autor, a questão da prova é um problema interno ao sistema, já que é ele quem determina os prazos, e até mesmo em que situações devem ser aceitos os nexos causais entre os fatos e direitos. As provas devem ser admitidas pelo Direito. Através de procedimentos dogmáticos institucionalizados, que são não mecânicos, mas constitutivos, faz-se um trabalho linguístico de transformar "questões indecidíveis em decidíveis, que de novo podem transformar-se em indecidíveis, até a decisão que termina a questão" Os procedimentos burocráticos institucionalizados, através dos papéis sociais, neutralizam o efeito as pressões sociais sobre o sistema jurídico. No processo judicial, podemos ser partes, advogados, promotores, agentes judiciais ou juízes. Há uma contínua interação entre os papéis, que já são configurados de antemão, e não propriamente das pessoas concretas. ${ }^{34}$

32 KELSEN, Hans. Teoria pura do direito. São Paulo: Martins Fontes, 1987. p. 257-258.

33 FERRAZ JUNIOR, Tercio Sampaio. Introdução ao estudo do direito: técnica, decisão, dominação. 4. ed. São Paulo: Atlas, 2003. p. 320.

34 FERRAZ JUNIOR, Tercio Sampaio. Introdução ao estudo do direito: técnica, decisão, dominação. 4. ed. 
3. Doze homens e uma sentença: o conceito-imagem do problema da verdade factual relacionada ao tema da justiça

Na cena inicial desta película, dirigida por Sidney Lumet, em 1957, temos uma tomada de câmara panorâmica que mostra o conceito-imagem da imponência do Tribunal do Júri, da cidade de Nova York, visto de sua escadaria, de cima para baixo. A câmera vai aos poucos descendo e dirigindo o nosso olhar para dentro, primeiro no saguão principal, depois no corredor, por fim, nos colocando diretamente na sala de audiência número 228 , onde o juiz profere a seguinte determinação normativa para o júri:

Juiz: "Ouviram um longo e complexo caso de homicídio em primeiro grau. Um homicídio premeditado é mais grave acusação em nossos tribunais. Ouviram os testemunhos, a lei lhes foi lida para ser aplicada ao caso. Agora é dever de vocês separar os fatos da versão. Um homem está morto, a vida de outro está em jogo. Se houver dívida razoável sobre a culpa do acusado, devem entregar-me o veredicto de "não culpado" se entretanto, não houver, devem em sã consciência declarar o acusado "culpado" O que quer que decidam, o veredicto deve ser unânime. No caso de julgarem o acusado culpado, o tribunal não considerará a hipótese de perdão. A sentença de morte é compulsória neste caso. Estão frente a grande responsabilidade. Obrigado".

A seguir, enquanto o júri deixa a sala, a câmera dá um close na face do jovem acusado, de origem latina, que mostra, em termos logopáticos, o sentimento da angústia de ser sentenciado à cadeira elétrica. É a única vez que vemos a sua face, ele é acusado de matar seu pai com uma facada no peito. Entramos na sala de votação do júri, que está abafada, parece ser o dia mais quente do ano e o ventilador não funciona. Todos os doze jurados são trancados para que o procedimento burocrático institucionalizado, em torno da decisão unânime, se concretize, nos termos da interpretação autêntica exposta por Hans Kelsen. Do ponto de vista jurídico, não temos seres humanos concretos naquela sala, mas apenas papéis institucionalizados, ligados à função de jurados. Eles não têm nomes naquela sala, apenas números.

A partir deste momento, vivemos os bastidores zetéticos e humanos daqueles personagens, o espectador é trancado na sala com eles, o mundo exterior não pode mais ser visto. O clima a ser construído é de discordância, angústia e dúvida. O filme evita, claramente, o tratamento maniqueísta, os personagens são ambíguos e profundamente humanos no seu desenvolvimento, demonstram ter virtudes e defeitos. O fato de se tratar de um órgão judicante coletivo nos permite ver, com mais didatismo, toda a complexidade 
humana que está por detrás da verificação jurídica do fato, que implica numa construção linguística interpretativa. A ação dramática não pode ser mais natural e espontânea, nos seus detalhes, pois é traduzida em vários longos planos-sequência, a extensão do corte entre os planos é longa e contínua, quase simulando uma discussão feita em tempo real. Os personagens combinam uma linguagem verbal contundente com uma expressiva linguagem corporal, que é bastante agitada. O suor escorre pelas faces nervosas, da impactante e expressiva fotografia em branco e preto. Eles não param sentados em seu lugar nem por um instante. $\mathrm{O}$ ritmo da montagem do filme é envolvente e o roteiro é preciso no seu desenvolvimento, em termos lógicos, não há uma cena supérflua na película.

O oitavo jurado, numa magistral atuação de Henry Fonda, demonstrando angustia reflexiva, olha para a janela, como se buscasse ver o mundo lá fora, a ordem do ser, mas é interrompido pelo décimo segundo jurado que diz, frivolamente: "bonita vista, o que achou do caso? Achei bem interessante, não havia pontos obscuros, entende o que digo? Tivemos sorte de pegar um homicídio". Antes que a votação comece, o clima geral é de descompromisso, faz-se piadas, lê-se o jornal, fala-se de trabalho, partindo da premissa superficial de que se trata de um caso óbvio. O sétimo jurado diz ao jurado líder (foreperson): "podemos ir embora rápido, não sei de vocês, mas tenho ingressos para o jogo de hoje, Yanks contra Cleveland".

No momento da votação, o filme mostra o seu poderoso elemento logopático central, ligado ao fenômeno decisório jurídico. O júri é composto por não especialistas em Direito, ele não interpreta a norma geral, que tipifica o homicídio como crime, mas deve verificar juridicamente o fato, através do exame da consistência das provas. Todos os jurados acabaram de acompanhar seis dias de audiência, com manifestação linguística da defesa, da acusação, das testemunhas e do próprio acusado. Onze jurados o consideram culpado, apenas um, o oitavo jurado, o considera não culpado. A partir daí, uma interessante interação comunicativa vai se estabelecer entre eles, na maior parte das vezes, extremamente nervosa e acalorada em termos emocionais. Trata-se da angústia da escolha da decisão traduzida em termos logopáticos, que mescla, no espectador, uma união de emoções de primeiro e segundo grau.

Os onze jurados que decidem pelo veredicto "culpado" demonstram ter apenas consciência da presença de aspectos formais no julgamento, no sentido proposto por Alf Ross. Apresentam também uma visão ingênua da linguagem como representação da realidade, são persuadidos pelo discurso da acusação, integralmente. Não percebem que eles próprios interpretam a interpretação do discurso probatório, a eles apresentada, previamente, na audiência. Após ouvirem a apresentação das provas, há uma clara confusão na mente deles entre o verdadeiro e o verossímil, entre o "fato verificado" e o "fato em si" Todos depositam uma certeza absurda em torno da suposta situação fática "o garoto matou seu pai". como se a tivessem visto com seus próprios olhos. Aderem aos 
discursos das testemunhas de acusação, os tomam como se fossem deles próprios, até parece que eles mesmos testemunharam a cena do crime. $\mathrm{Na}$ justificativa de seus votos, alguns se veem como imparciais. Eles só querem "citar os fatos", como o terceiro jurado, numa contundente atuação de Lee J. Coob, que reproduz o discurso, na íntegra, de uma das testemunhas, vizinha ao rapaz, morador do andar debaixo:

Terceiro jurado: "O velho morava embaixo do quarto onde houve o homicídio. Às $00.10 \mathrm{~h}$, na noite do homicidio, disse ter ouvido barulho. E que parecia de briga. E ouviu o rapaz gritar: "Eu vou te matar"! Um segundo depois ouviu o corpo cair. Correu até lá, abriu a porta e viu o rapaz fugindo. Chamou a polícia. Chegaram e acharam o pai esfaqueado. O legista precisou a hora da morte por volta da meianoite. Esses são os fatos. Não se pode refutá-los. O rapaz é culpado. Também sou sentimental. Ele só tem 18 anos, mas ainda assim deve pagar."

O décimo jurado tenta reproduzir, com suposta objetividade, a narrativa da testemunha feminina, que morava no prédio em frente. Ela alega ter olhado pela janela e visto, do outro lado da rua, o rapaz esfaquear o pai, às $00.10 \mathrm{~h}$, mesmo que, naquele exato instante, passasse um trem todo apagado, sem passageiros. Segundo o que supostamente ficou provado no tribunal, seria possível enxergar a janela da frente, através de um trem, nestas condições.

Décimo jurado: "Uma mulher deitada, sem poder dormir, de calor, entendem, levanta, olha pela janela e, do outro lado da rua, vê o rapaz esfaquear o pai. É precisamente $00.10 \mathrm{~h}$, tudo se encaixa. Olha ela conhece o rapaz desde pequeno. A janela dele é em frente. Ela jura que o viu matar"

$\mathrm{Na}$ especificação dos fundamentos da decisão de cada um, observamos uma interessante questão, uma rica pluriperspectiva, expressa a partir do ponto de vista de cada jurado. Algumas falas, potencializadas pelo eficiente uso do close-up, que mostra a expressiva linguagem facial de todos, revelam a diferente forma com que os jurados percebem a questão linguística e a sua própria subjetividade. A justificativa do oitavo jurado revela consciência da materialidade da interpretação, nos termos de Alf Ross, e está bem próxima à lógica do razoável de Recaséns Siches. Ela preconiza que todo julgamento deve, assumidamente, almejar o valor justiça, a prudência humana em favor dos menos favorecidos em termos sociais. Ele demonstra ter a consciência clara de que, no processo jurisdicional, as estimativas são feitas em termos concretos, a partir de visões particulares. Para tanto, valoram-se as provas e os fatos, escolhendo-se a norma pertinente.

Fatos idênticos são passíveis de valorações diversas. Da mesma forma, ele parece perceber o que disciplina Hans Kelsen ao alertar que o fato juridicamente verificado pode, eventualmente, não corresponder ao fato em si, haveria sempre uma margem de erro potencial. Neste sentido, se o júri verifica um fato que na realidade não ocorreu, a justiça 
como valor fica claramente comprometida, um inocente estaria sendo condenado à morte. Pelo sistema jurídico americano, o ônus da prova cabe à promotoria, mas havendo dúvidas na verificação jurídica do fato, não deve haver condenação. $O$ oitavo jurado diz, com reponsabilidade, que não se pode decidir sobre a vida de um jovem de dezoito anos em cinco minutos. Neste instante, inicia-se um antagonismo claro entre ele e o terceiro jurado, que aparece no diálogo:

Oitavo jurado: "E se errarmos? Este rapaz foi maltratado a vida inteira. Nasceu na pobreza. A mãe morreu quando tinha nove anos. Morou um ano e meio em orfanato, enquanto o pai esteve preso por estelionato. Não é um começo muito feliz. É um rapaz revoltado porque foi maltratado a vida inteira, todos os dias. Teve dezoito anos de muita infelicidade. Acho que lhe devemos umas palavras, é só. De acordo com os testemunhos, parece culpado. Talvez seja. Sentei no tribunal seis dias enquanto apresentavam as provas. Tudo parecia se encaixar tão bem que comecei a estranhar, ou seja, nada se encaixa tão perfeitamente. Queria perguntar várias coisas. Talvez não mudasse nada. Comecei achar que a defesa não confrontou as provas de forma efetiva. Deixou muitas coisas passarem. Comecei a me colocar no lugar do rapaz. Teria pedido outro advogado. Se fosse minha vida em jogo ia querer que meu advogado pusesse as testemunhas de acusação na parede. Só há uma pessoa que pode ser considerada testemunha, a outra diz que ouviu e viu o rapaz fugir depois de matar. E há provas circunstanciais. Esses dois são tudo o que a promotoria tem. E se estiverem errados?"

Terceiro jurado: "Como assim, errados? Então para que testemunhas?"

Oitavo jurado: "Não podem estar errados?"

Terceiro jurado: "Como assim? Estavam sob juramento."

Oitavo Jurado: "São pessoas. Pessoas erram. Não poderiam estar errados?"

O filme também não idealiza a imagem e a vida do acusado, que cresceu num cortiço miserável. Ele sempre teve uma vida difícil, mas já assumiu atitudes de violência desde muito jovem. Segundo informação dos autos, o rapaz, desde os cinco anos, apanhava do pai a socos. Com dez anos, foi ao juizado de menores, porque jogou uma pedra na professora, já com quinze foi para um reformatório. Roubou um carro e foi preso por isso. Foi pego duas vezes brigando com uma faca, é sabido que seria muito habilidoso com elas. Para complicar ainda mais o caso, através do testemunho de vizinhos, que o rapaz teria batido no pai, depois de uma briga, por volta das $19.00 \mathrm{~h}$ daquela noite. $\mathrm{O}$ acusado alega que depois de apanhar do pai teria ido direto a uma espelunca onde comprou 
um canivete que tinha cabos especiais. O rapaz que lhe vendeu a faca disse que era a única que tinha no estoque. Ele teria encontrado os amigos no bar, os quais viram a faca, mas foi embora às 20:45h e teria ido para casa, por volta das 22:00 h. Às 23:30h, alega ter ido ao cinema e ter perdido a faca, antes de voltar para casa, por volta das 3:10h, da manhã, quando encontra a polícia e o pai morto na sua casa, supostamente com a mesma faca. Ele é interrogado no local do crime e preso, pois não foi reconhecido por ninguém que estava no cinema e não consegue se lembrar dos nomes dos filmes que supostamente viu. Duas testemunhas vizinhas alegam tê-lo visto matar o pai e fugir, por volta das 00:10h.

As circunstâncias são incriminadoras para o acusado, mas o "fato em si" em torno da morte do pai do acusado é inacessível para os jurados, é inacessível para nós espectadores. O oitavo jurado, apesar de estar imbuído claramente por uma valoração humanista, solidária à condição de excluído do rapaz, inicia uma perspicaz discussão linguística em torno da coerência formal do discurso das provas apresentadas. Sua estratégia argumentativa é inteligente, na medida em que percebe haver um grande dissenso valorativo entre os jurados, cuja moralidade se mostra bastante relativa, no sentido kelseniano da expressão. Eles vêm de classes sociais diferentes, um deles, inclusive, viveu num cortiço, em condições semelhantes a do acusado. Outros demonstram ter um poder aquisitivo alto, um deles é corretor da bolsa de valores de Nova York. O mais impactante, em termos de conceito-imagem, é que vários deles, ao longo da discussão, deixam o seu papel institucionalizado de jurado, e mostram, de um ponto de vista zetético, os seus valores pessoais divergentes que acabam por influenciar, muitas vezes de forma inconsciente, a sua própria interpretação constitutiva dos discursos probatórios. Esta valoração nem sempre é humanista e razoável, muitas vezes está ligada a preconceitos sociais e traumas pessoais. O terceiro jurado relatou, olhando para a foto dos dois juntos, ter ensinado o filho a brigar quando criança. Aos dezesseis anos, o filho bateu nele saiu de casa depois disto, não mantém contato com ele há dois anos. Lembramo-nos, também, do que diz o décimo jurado, bem representado por Ed Begley, logo no início do debate, sua fala, aparentemente objetiva, revela, na verdade, grande preconceito social.

Décimo jurado: “Teve um julgamento justo. Quanto custa isto? Ouvimos os fatos, não quer que acreditemos no rapaz, sabendo o que é. Convivi com eles a vida toda. Não se pode acreditar em nada do que dizem. Sabem disso. Já nascem mentirosos"

A primeira inconsistência estrutural do discurso das provas, levantada pelo oitavo jurado, diz respeito à suposta raridade da faca utilizada no crime, que seria a mesma faca pertencente ao rapaz. Ele mostra uma faca idêntica que teria comprado, ilegalmente, numa tabacaria a duas quadras da casa do rapaz, e que teria custado seis dólares. Considera, nestes termos, que haveria a possibilidade dele ter mesmo perdido a faca e o pai ter sido esfaqueado com uma similar. Mais tarde, vai ser considerado, através 
da experiência do sexto jurado, que morou num cortiço, que o rapaz, por ser experiente como o uso deste tipo de faca, jamais a utilizaria de cima para baixo, como ocorreu no crime, mas sim, de baixo para cima É feita mais uma votação, se os onze mantiverem a seu veredicto de culpado, o oitavo jurado aceita concordar com eles e mudar o seu voto. Mas, neste momento, aparece mais voto para "não culpado" foi dado pelo nono jurado, retratado pela bela atuação de Joseph Sweeney, claramente o mais velho do grupo. Fica claro que ele é uma pessoa madura e ponderada, menos vítima de seus preconceitos e traumas, que teve a sua visão, em torno dos possíveis equívocos da linguagem, ampliada pela discussão iniciada pelo oitavo jurado. Ele diz:

Nono Jurado: “Ele não está dizendo que o rapaz é inocente. Apenas não tem certeza. Não é fácil se posicionar contra os outros. Ele fez uma jogada por apoio e eu lhe dei. O rapaz é provavelmente culpado, mas quero ouvir mais."

A seguir, o oitavo jurado percebe uma outra sutil inconsistência formal nos discursos das duas testemunhas, quando analisados conjuntamente. Mostra que, se o trem estava passando no exato da ocorrência do assassinato, como alega a testemunha que "viu" o crime da janela do prédio da frente, o idoso não poderia, ao mesmo tempo, ter "ouvido" o rapaz gritar enquanto o trem passava. Ele parece resgatar a ideia de Hans Kelsen quando considera que sendo a causalidade impossível, não se pode imputar consequências jurídicas aos fatos.

Oitavo jurado: "Um trem de seis vagões leva dez segundos passando por um ponto. Digamos que o ponto seja a janela do quarto do homicídio. Morei num segundo andar perto dos trilhos, quando o trem passa é quase insuportável. Mal se houve o que pensa. O velho que morava no apartamento de baixo disse que ouviu o rapaz dizer que o mataria. No segundo seguinte, o corpo foi ao chão. A vizinha da frente diz que viu o homicídio pela janela dos dois últimos vagões. O corpo foi ao chão enquanto o trem passava, portanto, o trem passou roncando pela janela do velho, dez segundos antes de o corpo cair. O velho teria de ter ouvido o rapaz gritar quando o trem passava. Não é possível que o ouvisse. Mesmo que ouvisse não reconheceria a voz. Acho que um testemunho que condena a morte deveria ser preciso sim"

Neste momento, estimulado pelo oitavo jurado, o nono jurado faz uma releitura retrospectiva, quase cinematográfica da linguagem corporal da testemunha idosa. Há um belo close-up de sua face e o processo psicológico de identificação/projeção é claro entre ambos. Por também ser idoso, ele se projeta na testemunha e com ela se identifica. Ele não diz que a testemunha mentiu deliberadamente, mas entende que ela, eventualmente, teria se forçado a acreditar que ouviu aquilo e que reconheceu o rosto do rapaz. 
Nono jurado: "Eu o observei por um longo tempo. O paletó estava rasgado debaixo do ombro. Você não notou? Como se vem a um tribunal assim? Era um senhor muito idoso e usava um paletó rasgado. Andou bem devagar até a tribuna. Puxava da perna esquerda e tentava esconder isto. Por que estava com vergonha. Acho que conheço este homem melhor do que vocês aqui. Este é um homem calado, amedrontado, insignificante, velho que nuca foi nada a vida inteira. Que nunca foi reconhecido ou teve seu nome nos jornais. Ninguém o conhece. Ninguém o cita. Ninguém lhe pede conselhos depois de setenta e cinco anos. Cavalheiros, é uma coisa triste não ter expressão alguma. Um homem como este precisa ser citado, precisa ser ouvido. Ser citado, ao menos uma vez, é muito importante para ele. Seria duro para ele se isolar em seu mundo".

O oitavo jurado também considera que, sendo o rapaz muito esperto, não haveria sentido em pensar que ele gritaria, ao cometer o crime, para toda a vizinhança ouvir. Diz que o advogado de defesa, escolhido pelo Estado, provavelmente não queria o caso, pois, sendo um caso com poucas chances de vitória, não traria louros para a carreira dele, a menos que se esforçasse bastante e que acreditasse na inocência do rapaz. É neste momento que oitavo jurado tem um novo insight, que não havia percebido antes, com relação à imprecisões linguísticas na narrativa do idoso. Para justificar o seu ponto de vista, ele chega a encenar a narrativa da testemunha, na sala do júri. Mostra, através de o seu próprio caminhar, que seria impossível para um velho manco, que teve derrame, ir do quarto à sala, em quinze segundos, tendo de percorrer três metros e meio no quarto, mais treze metros do corredor. Ao testar pessoalmente o tempo, andando a mesma metragem, arrastando a perna, ele verifica que o tempo gasto seria de quarenta e um segundos. Conclui que ele pode ter visto outra pessoa que julgou ser o rapaz.

A chuva começa, o tempo refresca e, metaforicamente, o ventilador volta a funcionar, como se ele simbolizasse o enfraquecimento do antagonismo e a presença marcante da razoabilidade humana na interação do julgamento. Ao longo dela, cada vez que a votação é refeita, mais jurados votam pelo veredicto "não culpado" Ocorre uma interessante contraposição de discursos entre o décimo primeiro jurado, que, claramente influenciado pela fala do oitavo jurado, defende o princípio da razoabilidade no veredicto. A seguir, temos a fala exaltada do décimo jurado, que deixa de lado a suposta crença na verdade dos fatos e assume, claramente, a interferência da sua subjetividade valorativa preconceituosa na leitura interpretativa das provas. Neste momento, todos na sala dão as costas para ele enquanto discursa. O exagero valorativo de sua fala é exposto numa causalidade impossível. Ela é calcada em torno da ideia de que todo desfavorecido é um mentiroso, um bêbado e um assassino, a qual nada tem a ver com a verificação do fato 
processual, do ponto de vista interativo. Isto a torna sem sentido, perante os demais, em termos de imputação normativa.

Décimo primeiro jurado: "Temos uma responsabilidade. Sempre achei algo notável da democracia. O fato de sermos convocados pelo correio para vir aqui decidir pela culpa ou não de um rapaz do qual nunca ouvimos falar. Não temos nada a perder ou a ganhar com o nosso veredicto. Isto é uma das razões pelas quais somos fortes não devíamos fazer disto algo pessoal."

Décimo jurado: “Sabem como essa gente mente. Já é uma coisa nata. Que diabos? Eles não sabem o que é a verdade. E não precisam de motivo algum para matar alguém. Ficam bêbados, bebem como gambá, todos eles. E se alguém morrer, morreu. A vida humana não significa o mesmo para eles. Claro que possuem coisas boas, sou o primeiro a reconhecer, conheci um casal que era bom, mas é exceção. Entendem? A maioria parece insensível. São capazes de tudo. Estão cometendo um grande equívoco. O rapaz é mentiroso! Sei tudo sobre eles. Eles não prestam! Não tem um que preste! Estas pessoas são perigosas, selvagens!"

A seguir, o oitavo jurado alerta que o preconceito, embora profundamente humano, dificulta ainda mais o acesso à verdade, em si, já muito complicado e difícil. Resume, de um ponto de vista zetético e logopático, o conceito-imagem da angustiante incerteza do julgamento, exposta numa interessante emoção de primeiro grau, que nos coloca ao lado dele, na sua dúvida existencial. Pela sua fala, percebemos, mais uma vez, os limites da verificação do fato processual, no sentido propugnado por Hans Kelsen. O que se discute, naquela sala, não é inocência real do acusado, pois esta é inacessível ao direito. O debate jurídico gira em torno da certeza em torno da verificação jurídica dos fatos, da existência ou não da dúvida razoável, e não do fato em si, que jamais será acessado por eles, ou pelo espectador.

Oitavo jurado: "É sempre difícil deixar os preconceitos fora de uma questão destas. Não importa para que lado vá, o preconceito sempre obscurece a verdade. Não sei qual é a verdade e suponho que ninguém aqui jamais saberá de fato. Nove pessoas aqui parecem achar que o réu é não culpado. Mas só estamos jogando com probabilidades. Podemos estar enganados, podemos estar deixando um homem culpado livre, não sei. Ninguém pode saber ao certo. Mas temos dúvida razoável. $\mathrm{E}$ isso é algo muito valioso no nosso sistema. Nenhum júri pode declarar um homem culpado a menos que tenha certeza. Nós nove não podemos entender como vocês três continuam com tanta certeza." 
No momento em que o quarto jurado reafirma o seu voto de culpado e reconstrói o discurso da testemunha feminina que alega ter visto o crime, como se, de fato, estivesse vendo o crime ele mesmo, naquele instante, ele faz um gesto curioso. Ele tira os seus óculos e passa as mãos no nariz, no lugar onde estes se apóiam. Neste momento, o nono jurado, que já havia demonstrado ter uma memória visual extraordinária em relação ao idoso, tem um novo insight, que passou despercebido, até mesmo pela astúcia linguística do oitavo jurado. Ele recorda que a testemunha feminina tinha marcas de óculos no nariz e as esfregava o tempo todo. A partir desta observação minuciosa, outros confirmam terem percebido o detalhe, inclusive o quarto jurado que estava tão certo da verdade imposta, minutos antes. O oitavo jurado considera que talvez, como o idoso, ela tenha pensado ter visto o acusado, mas, de fato, pode ter visto algo embaçado. Se ela estava na cama, tentando dormir, no momento em que supostamente viu o rapaz esfaquear o peito do pai, de cima para baixo, apenas virando o seu rosto, olhando para a janela, ela estava sem óculos, certamente. Mais uma vez, temos uma impossibilidade causal, ver uma pessoa na janela da frente, sem óculos através de um trem em movimento, no escuro, que torna impossível a imputação normativa ao fato.

O último a mudar de posição é o terceiro jurado, que parecia, até então, irredutível. Seu antagonismo com o oitavo jurado é explícito, já que situação inicial se inverteu. Temos onzes jurados favoráveis ao veredicto "não culpado" Antes de expor a sua fragilidade pessoal, ele faz uma tentativa desesperada, mas frustrada, de invocar, mais uma vez, a objetividade das provas. Todavia, acaba revelando, de forma extremamente passional, que estava projetando, a nível psicológico, o trauma de ter sido agredido e abandonado por seu filho. $\mathrm{Na}$ verdade, ele estaria condenando seu próprio filho, e não o acusado, através de processo mental, complexo, mais inconsciente. $\mathrm{O}$ confronto com o seu trauma é muito doloroso, mas o impulsiona a escolher, de forma mais racional, e menos perturbada por emoções negativas, o veredicto "não culpado" após rasgar a foto em que aparece ao lado do filho, já adulto. O julgamento termina, todos saem da sala levando consigo a impessoalidade de seus papeis, após proferir a interpretação autêntica dos fatos no veredicto "não culpado", no sentido kelseniano da expressão. Antes de deixar a sala, o oitavo jurado mostra consideração humana pelo terceiro jurado, entregando-lhe, gentilmente, o paletó, quando o vê arrasado psicologicamente. Mas, ao sair do tribunal, já perto da escadaria, o nono jurado pergunta o seu nome, num gesto final de encontro de pessoas, não mais de papéis, que acabaram sendo parceiros nesta empreitada humanista. $O$ oitavo jurado apenas reponde com um sorriso: "Davis" O nono jurado oferece a sua mão em cumprimento, dizendo, cordialmente: "Eu sou "MacCardle" Eles se despedem e cada um segue o seu caminho. 


\section{Considerações finais}

Pela análise do filme, relacionada a concepções teóricas no campo da Filosofia do Direito, ficou demonstrado o conceito-imagem ligado à impossibilidade de reduzirmos o raciocínio decisório a uma dedução silogística mecanicista, defendida pelas teorias dogmáticas tradicionais. A película evidencia a importância do impacto da compreensão logopática, emocional e afetiva, para a cognição completa de como as imprecisões linguísticas impossibilitam a defesa dogmática de um ideal de justiça absoluto, no momento do julgamento. $\mathrm{O}$ "fato em si" e a verdade factual jamais vão ser acessados pelo direito, no momento de sua aplicação. É ele que constrói e relativiza a verdade fática, em termos normativos, por isso há inerentes possibilidades de erro.

Através das emoções primárias, percebemos a angústia humana que afeta o sensível, mas perspicaz, oitavo jurado, diante desta incerteza, quando ela implica na decisão sobre a vida ou morte de uma pessoa. Pelas mesmas emoções, sentimos como as valorações humanas negativas, ligadas aos preconceitos, à falta de seriedade e aos traumas pessoais, que atingem outros jurados, dificultam ainda mais esta constituição dos fatos de forma razoável. Em termos concretos, há uma espécie de "meta-interpretação complexa" no fenômeno decisório, na medida em que os julgadores têm de interpretar uma interpretação prévia da realidade construída pelo próprio discurso probatório. Haveria imprecisões linguísticas e subjetividades valorativas nestes dois níveis de construção hermenêutica.

Mas, em termos de emoção secundária, o filme provoca uma angústia ainda maior, que diz respeito a uma potencial incompletude humana de quem julga um processo. Ele tornou evidente, nos termos colocados pelas teorias destacadas, como a verificação jurídica do fato envolve um permanente campo de incertezas, na medida em que depende de uma construção linguística competente, que não afeta a todos envolvidos nas tarefas judicantes, de forma unânime. Faz parte da natureza humana, ter uma visão humanista e responsável, mas nunca estaremos livres das valorações menos positivas, que nos afetam e que também fazem parte da condição humana, inexoravelmente.

Se o filme confirma as reflexões de Al Ross, no tocante a permanente integração da consciência jurídica formal, ligada ao respeito dogmático ao direito e da consciência jurídica material, ligada aos valores, nos raciocínio decisórios, surge, ao mesmo tempo, a percepção expandida, através do filme, de que esta materialidade está sujeita a distorções, e tem ser trabalhada, com responsabilidade. Onze jurados não tinham consciência desta materialidade relativa, que envolve uma escolha entre diferentes possibilidades, naquele julgamento. Apenas o oitavo jurado estava consciente do risco da injustiça de uma materialidade mal trabalhada e das incertezas linguísticas. Ele acabou dominando a cena, graças à sua astúcia argumentativa, associada a um senso de responsabilidade ético. Para nós, o contato com a linguagem artística é muito rico para expor este momento de complexidade, com maturidade, visando a construção de uma 
consciência jurídica material mais positiva, em termos humanos. Ele supera qualquer explicação teórica racional, pois tem de ser sentida, existencialmente.

Como na brilhante peça irlandesa de Brian Friel, Faith Healer, citada na introdução deste trabalho, os conceitos-imagem do filme Doze homens e uma sentença não nos conduzem à resposta fácil em torno do real, como ocorre em muitos filmes de tribunal hollywoodianos, que não hesitam em mostrar, em termos ideais e claramente fictícios, a suposta verdade factual no final. Iniciamos e terminamos nossa experiência logopática angustiados e presos na sala do júri, de forma bem próxima ao que ocorre na realidade concreta de um julgamento. Jamais saberemos o que aconteceu, de fato, jamais saberemos se o rapaz matou ou não o seu próprio pai. Apenas captamos as possibilidades não congruentes dos relatos discursivos narrativos do que poderia ou não poderia ter acontecido, em termos reais.

São Paulo, outubro de 2010

\section{Referências}

CABRERA, Julio. O cinema pensa: uma introdução à filosofia através dos filmes. Rio de Janeiro: Rocco, 2006.

DI GIORGI, Beatriz; CAMPILONGO, Celso Fernandes; PIOVESAN, Flávia (Coord.). Direito, cidadania e justiça: ensaios sobre lógica, interpretação, teoria, sociologia e filosofia jurídicas. São Paulo: Editora dos Tribunais, 1995.

FERRAZ JUNIOR, Tercio Sampaio. Direito, retórica e comunicação: subsídios para uma pragmática do discurso jurídico. São Paulo: Saraiva, 1973.

Introdução ao estudo do direito: técnica, decisão, dominação. 4. ed. São Paulo: Atlas, 2003. Teoria da norma jurídica: ensaio de pragmática da comunicação normativa. Rio de Janeiro: Forense, 1978.

KELSEN, Hans. Teoria pura do direito. São Paulo: Martins Fontes, 1987.

LUMET, Sidney. Doze homens e uma sentença (12 Angry Men). DVD, MGM Home Entertainment, 2004.

ROSS, Alf. Direito e justiça. Bauru: Edipro, 2003.

XAVIER, Ismail O discurso cinematográfico: a opacidade e a transparência. São Paulo: Paz e Terra, 2005.

(Org.). A Experiência do cinema: antologia. Rio de Janeiro: Edições Graal: Embrafilmes, 2008. 